\title{
RGD targeting of human ferritin iron-oxide nanoparticles enhances in vivo molecular MRI of experimental aortic aneurysms
}

\author{
Toshiro Kitagawa ${ }^{1 *}$, Hisanori Kosuge ${ }^{1}$, Masaki Uchida², Yasunori lida ${ }^{3}$, Ronald L Dalman ${ }^{3}$, Trevor Douglas², \\ Michael V McConnell ${ }^{1}$
}

From 15th Annual SCMR Scientific Sessions

Orlando, FL, USA. 2-5 February 2012

\section{Background}

Both inflammation and angiogenesis contribute to the progression of abdominal aortic aneurysm (AAA) disease. RGD is a peptide binder of the $\alpha v \beta 3$ integrin, which is expressed highly on activated macrophages and angiogenic endothelial cells. Human ferritin (HFn) is a nanoscale protein cage with $12 \mathrm{~nm}$ diameter and $8 \mathrm{~nm}$ interior cavity, which we have utilized as a platform for molecular/cellular imaging. We can genetically introduce RGD peptide to HFn. The purpose of this study is to evaluate RGD-conjugated HFn iron oxide nanoparticles for enhanced in vivo MRI of murine AAAs.

\section{Methods}

1) Mice - Murine AAAs were induced in Apo-E deficient mice by angiotensin II infusion $(1 \mu \mathrm{g} / \mathrm{kg} / \mathrm{min})$, followed by monitoring of aortic diameter by ultrasound. Control mice were created by saline infusion.

2) RGD-conjugated HFn-iron oxide nanoparticles HFn was genetically engineered to display 24 copies of an RGD peptide on the exterior surface of the protein cage. Magnetite $\left(\mathrm{Fe}_{3} \mathrm{O}_{4}\right)$ was encapsulated in the interior cavity of RGD-conjugated HFn $\left(\mathrm{RGD}^{+}\right)$and non-targeted HFn $\left(\mathrm{RGD}^{-}\right)$at loading factors of $5000 \mathrm{Fe}$ per cage, giving R2 values of $93 \mathrm{mM}^{-1} \mathrm{~s}^{-1}$ (magnetite diameter: 5$7 \mathrm{~nm}$ ). The injected dose was adjusted to $25 \mathrm{mgFe} / \mathrm{kg}$ in each animal.

3) $M R I$ - All mice were imaged on a whole-body $3 \mathrm{~T}$ MRI scanner (Signa HDx, GE Healthcare) with a phased array mouse coil (RAPID MR International), using a gradient echo sequence $(\mathrm{TR} / \mathrm{TE}=100 \mathrm{~ms} / 10 \mathrm{~ms}$, slice

${ }^{1}$ Cardiovascular Medicine, Stanford University School of Medicine, Stanford, CA, USA

Full list of author information is available at the end of the article thickness $=1.0 \mathrm{~mm}, \mathrm{FOV}=3 \mathrm{~cm}$, matrix $=256 \times 256, \mathrm{FA}=60$, $\mathrm{NEX}=10)$. Mice were then injected with either $\mathrm{RGD}^{+}$or RGD $^{-}$(6 AAA and 4 control mice for each), followed by MRI at 24 and 48 hours post injection. The nanoparticle accumulation was assessed by measuring the reduction in the T2\%-weighted signal intensity of the AAA (or suprarenal aorta in control mice) relative to adjacent normal-size aorta (expressed as \% SI loss).

4) Histology - The aortic wall was stained with Perl's iron (for nanoparticle accumulation), CD-11b (for macrophages), and CD-31 (for endothelial cells).

\section{Results}

MRI showed greater T2" signal loss in the AAA with $\mathrm{RDG}^{+}$than with $\mathrm{RDG}^{-}$(Fig $1(\mathrm{~A})$ ), confirmed by

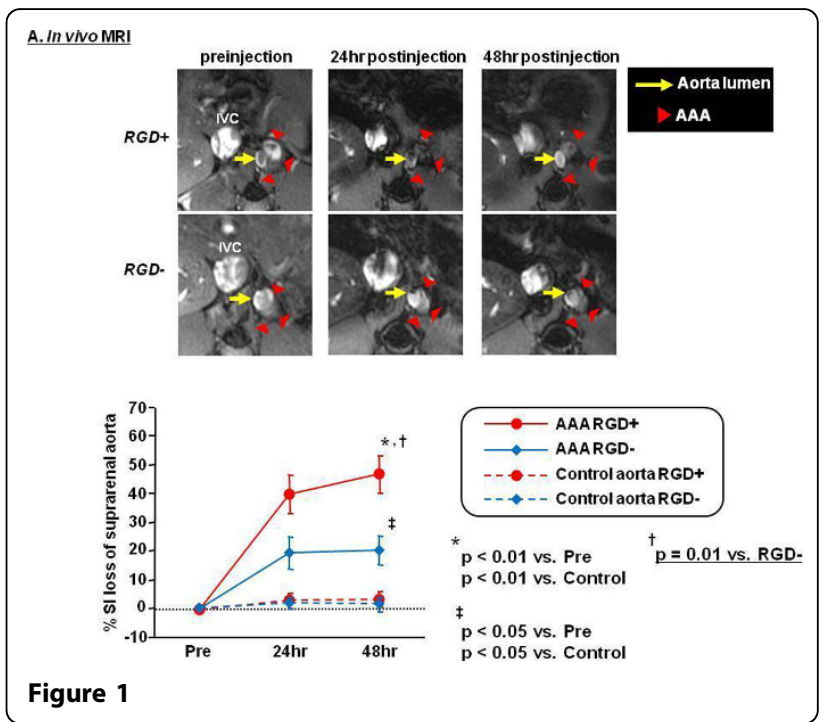




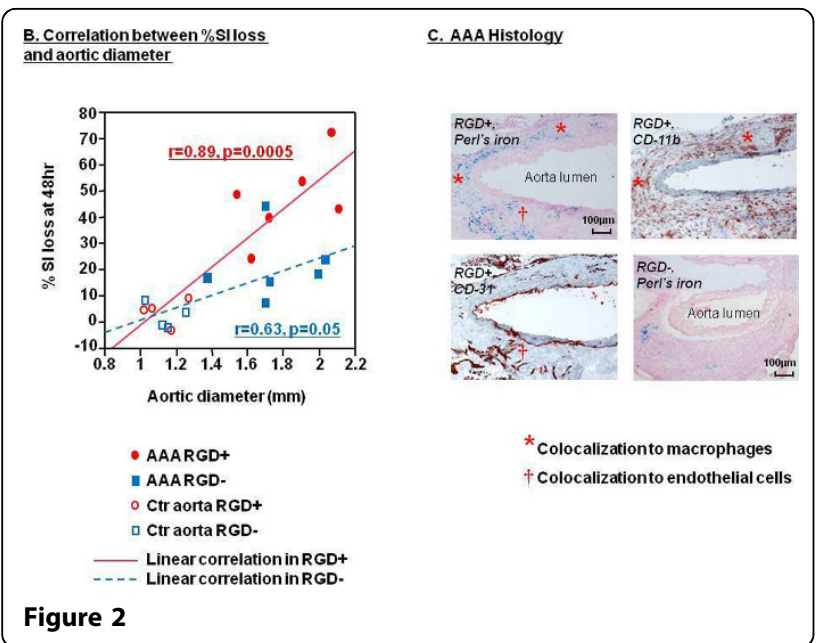

quantitative analysis of \% SI loss (Fig 1(A) graph, $\mathrm{p}=0.01$ ). Abdominal aortic diameter on ultrasound correlated more strongly with \% SI loss with $\mathrm{RDG}^{+}$than with RDG ${ }^{-}$(Fig 2(B)). Perl's iron staining confirmed greater accumulation of $\mathrm{RDG}^{+}$in the AAA compared to RGD $^{-}(474 \pm 51$ vs. $277 \pm 29$ stained cells/cross-sectional area, $\mathrm{p}=0.01$ ), with colocalization to both macrophages (CD-11b) and endothelial cells (CD-31) within the AAA wall (Fig 2(C)).

\section{Conclusions}

HFn iron-oxide nanoparticles with RGD targeting provide a promising MRI approach for comprehensive in vivo detection of inflammation and angiogenesis in high-risk AAAs.

\section{Funding}

Dr. McConnell receives research support from GE Healthcare and he is on a scientific advisory board for Kowa, Inc.

\section{Author details}

${ }^{1}$ Cardiovascular Medicine, Stanford University School of Medicine, Stanford, CA, USA. ${ }^{2}$ Chemistry and Biochemistry, Montana State University, Bozeman, MT, USA. ${ }^{3}$ Vascular Surgery, Stanford University School of Medicine, Stanford, CA, USA.

Published: 1 February 2012

\section{doi:10.1186/1532-429X-14-S1-M9}

Cite this article as: Kitagawa et al:: RGD targeting of human ferritin ironoxide nanoparticles enhances in vivo molecular MRI of experimental aortic aneurysms. Journal of Cardiovascular Magnetic Resonance 201214 (Suppl 1):M9.
Submit your next manuscript to BioMed Central and take full advantage of:

- Convenient online submission

- Thorough peer review

- No space constraints or color figure charges

- Immediate publication on acceptance

- Inclusion in PubMed, CAS, Scopus and Google Scholar

- Research which is freely available for redistribution 